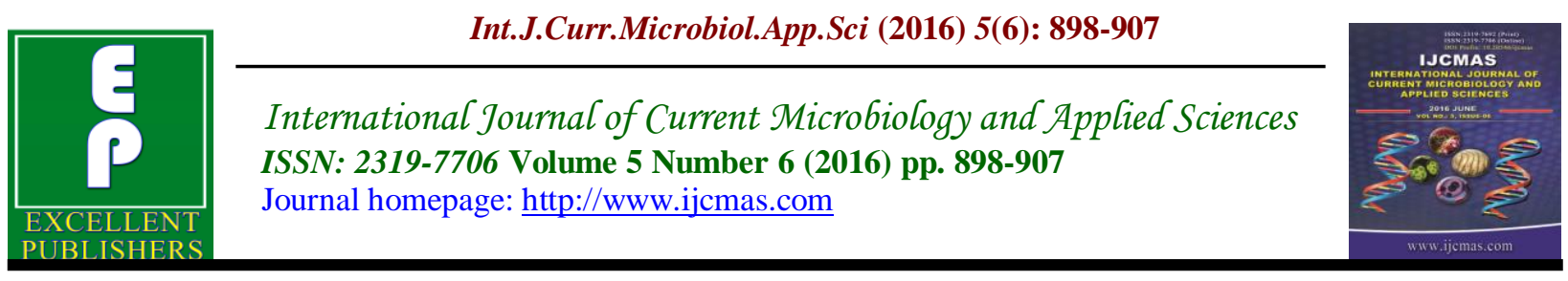

Original Research Article

http://dx.doi.org/10.20546/ijcmas.2016.506.097

\title{
Screening and Characterization of Cellulose Degrading Bacterial Isolates of Waste disposal Site
}

\author{
Vinay Mohan Pathak* and Ajeet Singh, Navneet \\ Department of Botany \& Microbiology, Gurukul Kangri University, \\ Haridwar 249-404, Uttarakhand, India \\ *Corresponding author
}

Keywords

Cellulose, carboxymethyl cellulase, bacteria, enzymes

\section{Article Info}

Accepted:

30 May 2016

Available Online:

10 June 2016

\section{A B S T R A C T}

Cellulose is an abundant natural biopolymer on earth and most dominating agricultural waste. Cellulosic biomass is a renewable and abundant energy source with great potential for bioconversion to value-added bio-products. Cellulose can be degraded by cellulase producing bacteria which is most important biocatalysts for the industrial process. Under favorable environmental conditions, such enzymes facilitate the degradation of cellulosic material and stored carbon in the form of carbon. These microorganisms are diverse in nature and occur in a different habitat. In present investigation isolates were investigated for cellulose degrading potential. Four isolates V8, C25, V1, V4 were Bacillus sp., Pseudomonas sp., Pseudomonas $s p$. and Acinetobacter $s p$. screened for cellulose degradation. Carboxymethyl cellulose solution was used to analyze the cellulose degradation. Each isolates were examined for cellulose degradation potential with endo $\beta-1,4$ glucanase activity and exo- $\beta-1,4$ glucanase activities. All four tested isolates were showed good positive for both endo and exo $\beta-1,4$ glucanase activity and cellulose degradation potential with $33.33 \%, 8.53 \%, 3.84 \%, 3.12 \%$ weight loss, by isolates V1, V8, V4, C 25 respectively.

\section{Introduction}

Polymer material like cellulose is most common organic compound existing on earth and plants are major source of renewable carbon and energy. About 200 gigatons of $\mathrm{CO}_{2}$ are fixed of earth every year and the equivalent amount of organic material has to be degraded approximately $30 \%$ by plants and animals to $70 \%$ by microorganisms. On average, cellulose accounts as $50 \%$ of the dry weight of plant biomass. Cellulose is the renewable biopolymer with dominating agriculture waste [Shanmugapriya et al., 2012; Patagundi et al., 2014; Pandimadevi \& Begum, 2013]. Cellulose is one of the most abundant raw materials for microorganisms as food and energy source and these microorganisms play a critical role to degrade cellulose is used to produce energyyielding product eg. ethanol. Degradation of cellulosic material is depends on the availability of hydrolytic enzymes and microorganisms are one of the prominent sources for the hydrolytic enzyme. These 
microorganisms exploited commercially for the production of polymer-degrading enzymes [Coughlan, 1985; Shanmugapriya et al., 2012; Patagundi et al., 2014; Nwagu et al., 2012].

Microbes are very important for human being due to their symbiotic nature, it can serves as food, feed, medicine etc. because of their uncountable use in the different area. It is known as natures 'master chemists'. Nowadays numbers of microbial species were used to produce beneficial products [Anne and Ann, 2007]. The divers nature of microorganisms appear in the environment with their especial properties i.e. adaptation in adverse environmental conditions, such as extremes temperature, $\mathrm{pH}$ and salt concentrations. The distinctive feature of the natural environment is that it offers as an inimitable source of microorganisms .The propensity of existing in adverse climatic conditions comes from biodiversity and adaptation nature of microorganisms. These conditions accelerate the biochemical changes in microorganisms and enhance the enzyme stability and survival rates of microorganisms in adverse environmental conditions. Extreme environmental conditions force the microorganisms to produce new proteins, enzymes that also widely use in industrial methods [Shanmugapriya et al., 2012; Patagundi et al., 2014; Shu et. al., 2013; Lone et al., 2014].

Cellulose is the largely occurring natural polymer in the environment. It mostly found in plants biomass (cell walls) as the structural polysaccharide. Cellulose contributes 35 to 50 percent of plant dry weight. Cellulose is made up of structural units of glucose molecules. These molecules link to each other via $\beta-1,4$ glucoside linkage [Lynd et al., 1999; Zhang and Lynd, 2004]. Degradation of cellulose also important for glucose production point of view. Glucose is the well known simplest carbohydrate sugar and exploited as the alternative energy source for industrial processes. [Lone et al., 2014] Instead biodegradation and enzymatic hydrolysis the other ways of cellulose hydrolysis is a tedious approach, by mean production and recovery of products. In acid hydrolysis, byproducts generate hindrance during the recovery process [Cooney et al., 1978; Fennington et al., 1982; Shanmugapriya et al., 2012].

Microbial degradation of cellulose is contributing much amount of carbon flux to the atmosphere and also important for composting and anaerobic digestion. [Lee et al., 2002] Microbial (bacteria and fungi) originated hydrolytic enzymes are broadly uses in industrial processes. Cellulolytic bacteria are well known in natural environment belonging from genus Bacillus, Pseudomonas, Acidothermus, Cellulomonas, Streptomyces, Micromonospora, Caldibacillus, Acetivibrio, Clostridium, Ruminococcus, Spirochaeta, Anaerocellum etc. [ Patagundi et al., 2014; Kim, 1987; Bergquist et al., 1999; Bagnara et al., 1987; Bagnara et al., 1985; Wachinger et al., 1989; Gallagher et al., 1996; Godden et al., 1984; Khan et al., 1984; Ljungdahl et al., 1984; Svetlichny et al., 1990; Shanmugapriya et al., 2012; Lin et al., 2012] and microorganisms also reported for the degradation of modified cellulose (CMC), such as Polyporus arcularius [Manavalan et al., 2015]. Cellulase one of the prominent family of enzymes that use for cellulose degradation. [Maki et al., 2011] Absolute degradation of cellulose is accomplished in viro by an especial group of enzyme. The group of enzyme involves in hydrolysis of crystalline are (1) Exo- $\beta-1,4$ glucanase (2) Endo- $\beta$-1, 4 glucanase (3) $\beta$ glycosidase [Bhat, 2000; Sadasivam and 
Manickam, 1991]. Exo- $\beta-1,4$ glucanase is the enzyme that initiates the hydrolysis. Exo- $\beta-1,4$ glucanase generating cellobiose molecules by cleaving the bound from nonreducing end of cellulose. $\beta$-glycosidase play key role, it hydrolyzes the cellobiose. Microorganisms able to producing exo- $\beta-1$, 4 glucanase are capable to hydrolyzing native cellulose (filter paper, cotton etc.). [Shi et al., 2011; Shu et. al., 2013; Sadasivam and Manickam, 1991] Carboxymethyl cellulose (CMC) serves as modified celluloses. Carboxymethyl cellulose exploited as substrate to analyses cellulase. [El Ahwany \& Mohamed, 2008] Microorganisms have great potential to degrade cellulosic material and such approach needs to the intense research on isolation, characterization of new strains of microorganisms. [Demain and Solomon, 1985]Present research focus on characterization of cellulose-degrading microorganisms. The cost of enzymes also depends on its productivity, if there is suitable strains are available then the productivity is high and cost of enzyme production is economic [Nwagu et al., 2012].

\section{Materials and Methods}

\section{Chemicals and Media}

Carboxymethyl cellulose (CMC) powders were used (purchased from Merck Specialities Private Limited, Mumbai) in present study.

\section{Screening of Bacterial Isolates for Cellulose utilization}

A total 10 bacterial strains were selected for screening, these bacterial strains got from departmental culture collection, which were isolated from waste disposable sites. Selected bacterial isolates were examined for cellulose consumption as a primary carbon source. These isolates were incubated in nutrient broth for 24 hours at 37 ${ }^{\circ} \mathrm{C}$ to prepared active culture. [Soni, et al., 2009] Overnight grown culture was transfer to the agar plate containing $1 \% \mathrm{CMC}$. Plates were incubated for 5 days to allow bacterial growth and enzymatic activity. After the incubation, plates were visualized to hydrolysis of CMC agar medium. CMC agar plates were flooded $1 \%$ Congo red aqueous solution for 15 minutes at room temperature. Plates were poured off and further treated with $1 \mathrm{M} \mathrm{NaCl}$ for 15 minutes. The cellulase activities of bacterial strains were observed by zone hydrolysis [Nwagu et al., 2012; Lone et al., 2014; Pandimadevi and Begum, 2013; Duza and Mastan, 2015; Shanmugapriya et al., 2012].

\section{Biochemical and Molecular Characterization}

Out of ten only four isolates V8, C $25, \mathrm{~V} 1$ and V4 were screened based on experiment. Biochemical characterization was done according to Bergey's manual by using biochemical testing kits (HiCarbo ${ }^{\mathrm{TM}}$ Kit KB009, KB003 purchased from Himedia laboratories Pvt. Ltd. India). Molecular characterization was done by using $16 \mathrm{~S}$ rDNA sequence. PCR (polymerase chain reaction) amplification of $16 \mathrm{~S}$ rRNA gene was done by using $27 \mathrm{f}$ CCAGAGTTTGATCMTGGCTCAG 3') and 1492r (5'TACGGYTACCTTG TTAC GACTT 3') set of bacterial primer. Amplified DNA products was sequenced and blast search on NCBI GenBank. [Patagundi et al., 2014; Soni, et al., 2009]

\section{Measurement of Cellulase Activity}

The crude enzyme was extracted from the culture. The samples were taken from incubated broth and centrifuged at $14000 \mathrm{~g}$ 
for 10 minutes at $4{ }^{\circ} \mathrm{C}$, supernatant was collected for further examination of crude enzyme. This assay conducted to analyze exo $\beta-1,4$ glucanase and endo $\beta-1,4$ glucanase activity. [Shu et. al., 2013; Decker et al., 2003; Nwagu et al., 2012; Shi et al.,2011]

\section{Assay for endo $\beta$-1, 4 glucanase}

The viscometric method was used to determine the endo $\beta-1,4$ glucanase activities by analyzing the viscosity reduction in CMC solution. The $3 \mathrm{ml}$ of 0.5 $\%$ carbooxymethyl cellulose solutions was mixed with $1 \mathrm{ml}$ of $0.1 \mathrm{M}$ citrate phosphate buffer solution and $1 \mathrm{ml}$ of crude enzyme extract added with $0.1 \mathrm{ml}$ antibiotic (chloramphenicol cyclohexamide) solution that prevents the sample from microbial contamination. After mixing of all solution with the enzyme, it incubated for 16 hours at $37{ }^{\circ} \mathrm{C}$. Control was prepared by adding denatured enzyme (crude enzyme denatured by boiling) extracts. Incubated samples boiled in a water bath for 2-4 minutes and centrifuged at $8000 \mathrm{~g}$ for 20 minutes. Supernatant was tested, measuring and viscosity was measured [Sadasivam and Manickam, 1991].

\section{Viscosity reduction measured by formula}

Percentage loss in viscosity $(\mathrm{V})=\left(\mathrm{T}_{0^{-}} \mathrm{T} / \mathrm{T}_{0^{-}}\right.$ $\mathrm{T}_{\mathrm{H} 2 \mathrm{O}}$ ) $\mathrm{x} 100$. Where $\mathrm{T}_{0}$ is the flow time before incubation, $\mathrm{T}$ is the flow time after incubation and $\mathrm{T}_{\mathrm{H} 2 \mathrm{O}}$ is the flow time of water [Duza and Mastan, 2015; Sadasivam and Manickam, 1991; Shu et. al., 2013].

\section{Assay for exo- $\beta-1,4$ glucanase}

The production of reducing sugar by the exo- $\beta-1,4$ glucanase activities and were determined by 3, 5-dinitro salicylic acid (DNS) method. The $50 \mu$ l enzyme extract was added to $450 \mu \mathrm{l}$ of $1 \%$ carbooxymethyl cellulose solutions (1\% CMC solution prepared in $0.1 \mathrm{M}$ sodium citrate buffer) and incubated for 15 minutes at $55{ }^{\circ} \mathrm{C}$ in water bath. Incubation samples were removed from and $500 \mu \mathrm{l}$ DNS reagent were added and boiled for 5 minutes. After boiling $1 \mathrm{ml}$ potassium sodium buffer added on samples. Samples were placed for measuring absorbance at $540 \mathrm{~nm}$ by spectrophotometer (Systronics 2201) and compared the absorbance to standard glucose curve. Glucose molecule released per unit mg protein expressed the enzyme activity. [Duza and Mastan, 2015; Sadasivam and Manickam, 1991; Shu et. al., 2013]

\section{Estimation of glucose DNS method}

The glucose reducing the 3, 5-dinitro salicylic acid (DNS) and reddish color was produced and its intensity measured at 540 nm by spectrophotometer (Systronics 2201). DNS reagent prepared by dissolving $1 \mathrm{gm} 3$, 5-dinitro salicylic acid, $200 \mathrm{mg}$ crystalline phenol and $50 \mathrm{mg}$ sodium sulphite in 100 $\mathrm{ml}$ of $1 \% \mathrm{NaOH}$. Glucose solution prepared with different concentration $(0.01 \mathrm{mg} / \mathrm{ml}$ to $0.1 \mathrm{mg} / \mathrm{ml}) .1 \mathrm{ml}$ of glucose solution added with $3 \mathrm{ml}$ DNS reagent and placed on the water bath, boil for 20 minutes and purple color developed [Sadasivam and Manickam, 1991].

\section{In vitro Biodegradation}

\section{Biodegradation assay by weight loss}

A volume of $100 \mathrm{ml}$ of Minima broth Davis w/o dextrose (purchased from Himedia laboratories Pvt. Ltd. India) media amended with pre-weight pieces of Whatman filter paper ( $\mathrm{pH} 7.0 \pm 0.2)$ into $250 \mathrm{ml}$ Erlenmeyer flask. Flasks were inoculated with $100 \mu \mathrm{l}$ aliquots of active culture and incubated at 37 ${ }^{\circ} \mathrm{C}$ degraded samples were removed at 
stationary phage and compared the weight loss of control (without bacterial culture). [Soni, et al., 2009; Pandimadevi and Begum, 2013; Nwagu et al., 2012; Lone et al., 2014]

\section{Paper Chromatography}

Biodegraded compounds were determined by paper chromatography. Paper chromatography was done by following chloroform:acetic solvent system in the ratio of $7: 3$. For 30 minutes.

\section{Result and Discussion}

The total 10 bacterial cultures were examined and out of ten only four isolates were found to suitable for cellulose degradation. All bacterial strains were originally isolated from polymer contaminated waste disposal sites. The previous researcher reported that in addition of some chemical (eg. glucose, acetic acid, maleic anhydride, ethanol etc.) increases the degradation rate of the natural polymer, synthetic polymer and municipal solid waste. [Singh, B., and Sharma, 2008; Raut et al., 2008; Soni, et al., 2009; Nanda and Sahu, 2010; Gabhane, et al., 2012] In Gram's staining determination isolated V8 was Gram positive while other three (C 2 5, V1 and V4) were Gram negative. All four isolates were characterized biochemically and further by molecular identification. Molecular identification was done by $16 \mathrm{~S}$ rDNA sequencing and sequence similarity was checked in data base of NCBI-Gene bank. And isolates were identified as Bacillus sp. strain V8 (accession numbersKT860420), Pseudomonas sp. strain C 25 (accession numbers- KT860422), Pseudomonas sp. strain V1 (accession numbers- KT860423), Acinetobacter sp. strain V4 (accession numbers- KT860424). Apparently, microbes are divers in nature with different type enzymatic activity reported for polymer (natural and synthetic) degradation.[ Patagundi et al., 2014; Singh, B., and Sharma, 2008; Raut et al., 2008; Soni, et al., 2009; Nanda and Sahu, 2010; Gabhane, et al., 2012; Duza and Mastan, 2015; Pandimadevi and Begum, 2013; Lone et al., 2014] Exploitation of these natural occurring microorganisms is suitable approach to cellulose degradation.

\section{Assay of Enzymatic Activity}

Measurement of enzymatic activity was conducted for selected isolates. Hydrolytic activity of endo $\beta-1,4$ glucanase was measured by calculating reduction in viscosity of carbooxymethyl cellulose solutions. Bacterial strain V4 showed highest hydrolytic activity in compared to other shown in table 1. Percentage reduction in $\mathrm{CMC}$ viscosity by bacterial isolates shown in figure 1. Estimation of endo $\beta-1,4$ glucanase was measured by DNS method. Glucose standard curve was prepared by DNS method shown in figure 2. Production of glucose with chromogenic agents in enzymatic hydrolysis and absorbance was measured at $540 \mathrm{~nm}$ by the spectrophotometer. The enzyme activity express as $\mathrm{mg}$ glucose released/minute/mg protein and maximum enzyme activity were found with bacterial isolate V1 shown in figure 3 [Sadasivam and Manickam, 1991; Shu et. al., 2013].

\section{Biodegradation Assays}

Cellulose biodegradation assays were performed by screened isolates with cellulose paper pieces. Pre-weighted paper pieces were added to minimal broth with bacterial isolates. After the one month of incubation, incubation paper pieces were recovered at stationary phases and measured the degradation by calculating the percentage weight loss. The results of 
percentage weight loss were shown in table 2. Highest bacterial growth was found at stationary phases. Bacterial isolate V1 showed maximum biodegradation with
$33.33 \%$ weight loss. Biodegradation of polymers was further determined by $\mathrm{CO}_{2}$ emission [Nanda et al., 2010].

Table.1 Determination of viscosity reduction

\begin{tabular}{|c|c|c|c|c|}
\hline S.N. & Bacterial Isolates & $\mathrm{T}_{0}$ & $\mathrm{~T}$ & $\begin{array}{c}\text { Viscosity reduction in } \\
\text { CMC solution (\%) }\end{array}$ \\
\hline 1 & $\mathrm{~V} 8$ & 19.48 & 2.16 & 90.87 \\
\hline 2 & $\mathrm{C} 25$ & 11.06 & 3.34 & 72.25 \\
\hline 3 & $\mathrm{~V} 1$ & 9.10 & 1.06 & 92.62 \\
\hline 4 & $\mathrm{~V} 4$ & 14.17 & 1.10 & 95.05 \\
\hline
\end{tabular}

Table.2 Polymer (cellulose) degradation by bacterial isolates

\begin{tabular}{|l|l|l|}
\hline S.N. & Microbial degradation (weight loss percent) \\
\hline & Isolates & $\begin{array}{l}\text { Degradation percentage of polymer } \\
{[\%]}\end{array}$ \\
\hline 1 & Control & 0 \\
\hline 2 & V 8 & 8.53 \\
\hline 3 & C 25 & 3.12 \\
\hline 4 & V 1 & 33.33 \\
\hline 5 & V4 & 3.84 \\
\hline
\end{tabular}

Fig.1 Percentage reduction in CMC viscosity by bacterial isolates.

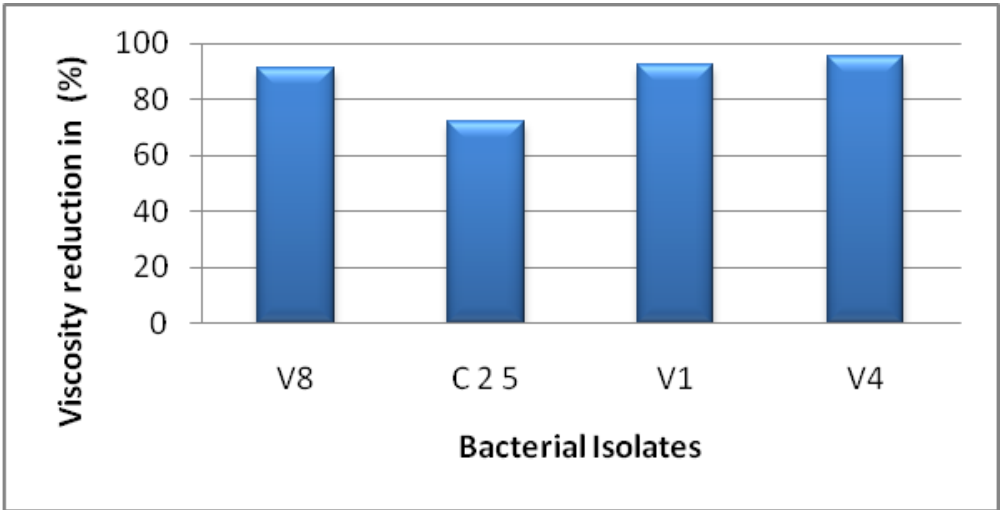


Fig.2 Glucose standard curve

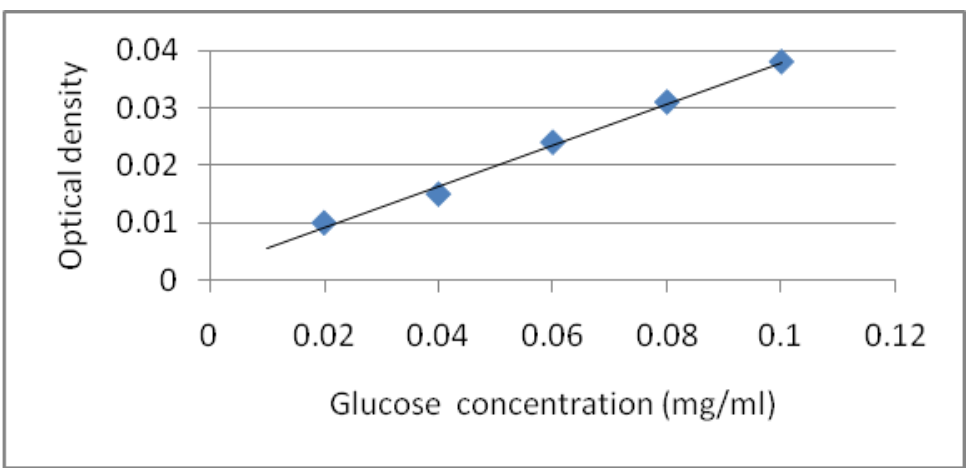

Fig.3 Enzymatic activity (mg of glucose release/minute/mg protein) of bacterial isolates

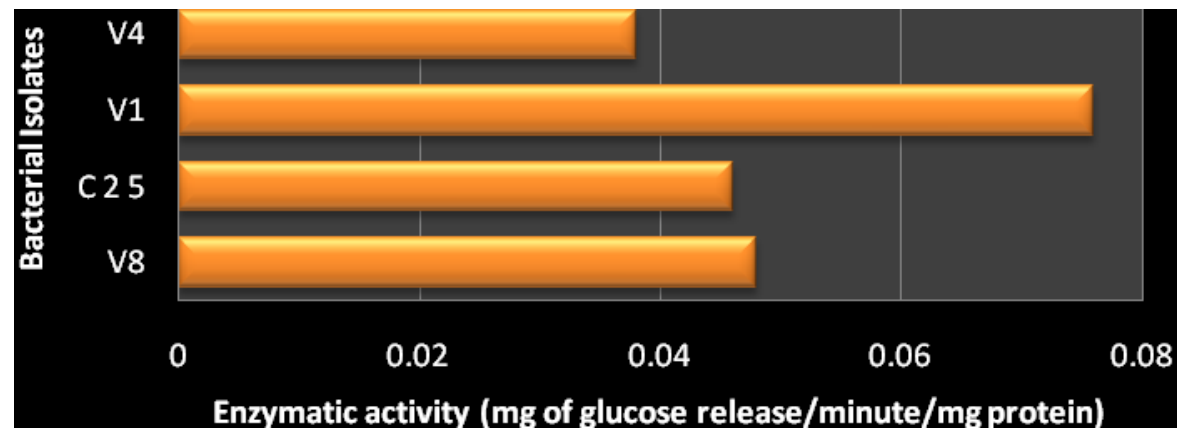

\section{Paper Chromatography}

Paper chromatography was done by chloroform:acetic acid solvent system with the ration $7: 3$. The $\mathrm{Rf}$ value of control with 0.42 and $\mathrm{Rf}$ values with $0.68,0.47,0.46$, 0.45 for treat samples by $\mathrm{V} 1, \mathrm{~V} 8, \mathrm{~V} 4$ and $\mathrm{C}$ 25 respectively.

In conclusion, the present work was carried out for cellulose degradation, characterized screened biochemically and identified by molecular analysis and determined their cellulose degradation efficiency. Out of 10 isolates, 4 bacteria strains were screened and selected to determine their cellulose degradation potential. All four isolates showed exo and endo $\beta-1,4$ glucanase activity and V1 isolated showed maximum degradation. Present studied showed significant results and these bacterial isolates use in future as the promising approach for cellulose degradation and also for glucose production. Optimization of growth conditions enhances the productivity rate of the enzyme.

\section{References}

Anne, J. and Ann R., 2007. The new science of metagenomics: revealing the secrets of our microbial planet. 1 st edn., National Academies Press, 148.

Bagnara, C., Gaudin, C., laich J.P.B., 1987. Physiological properties of Cellulomoma fermentans, a mesophilic cellulolytic bacterium. App. Microbiol. Biotechnol. 26, 170176.

Bagnara, C., Toci, R., Gaudin, C., Belaich, J.P., 1985. Isolation and Characterization of a Cellulolytic Microorganism, Cellulomonas 
fermentans sp. nov. Int. J. Sys. Evo. Microbiol., 35(4), 502-507.

Bergquist, P.L., Gibbs, M.D., Morris, D.D., Te'o, V.S.J., Saul, D.J., Morgan, H.W., 1999. Molecular diversity of thermophilic cellulolytic and hemicellulolytic bacteria. FEMS Microbiol. Ecol. 28, 99-110.

Bhat, M.K., 2000. Cellulases and related enzymes in biotechnology. Biotechnol. Adv., 18(5), 355-383.

Cooney, C.L., Wang, D.I.C., Wang S.D., Gordon, J., Jiminez, M., 1978. Simultaneous cellulose hydrolysis and ethanol production by a cellulolytic anaerobic bacterium. Biotechnol. Bioeng., 8, 103-114.

Coughlan, M.P., 1985. The properties of fungal and bacterial cellulases with comments on their production and application. Biotechnol. Gene. Eng. Revo., 3, 36-109.

Decker, S.R., Adney, W.S., Jennings, E., Vinzant, T.B., Himmel, M.E., 2003. Automated filter paper assay for determination of cellulase activity. In Biotechnol. Fue. Chem., 689-703.

Demain, A.L., Solomon, N.A., 1985. Biology of industrial organisms. Benjamin/Cummings Publishing Co., Inc.. 573.

Duza, M.B., Mastan, S.A., 2015. Optimization studies on cellulase production from Bacillus anthracis and Ochrobactrum anthropic (YZ1) isolated from soil. Int. J. App. Sci. Biotechnol., 3(2), 272-284.

El Ahwany, A.M., Mohamed, E.A., 2008. Enzymatic hydrolysis of pseudoplastic paint thickener (hydroxyethyl cellulose) by a local isolate of Aspergillus niger. Afri. J. Biotechnol. 7(20), 3765-3770.

Fennington, G., Lupo, D., Stutzenberger, F., 1982. Enhanced cellulase production in mutants of Thermomonospora curvata. Biotechnol. Bioeng., 24, 2487-2497.

Gabhane, J., William, S.P., Bidyadhar, R., Bhilawe, P., Anand, D., Vaidya, A.N., \& Wate, S.R. 2012. Additives aided composting of green waste: Effects on organic matter degradation, compost maturity, and quality of the finished compost. Biore. Tech., 114, 382-388.

Gallagher, J., Winters, A., Barron, N., McHale, L., McHale, A.P., 1996. Production of cellulase and $\beta$ glucosidase activity during growth of the actinomycete Micromonospora chalcae on cellulose-containing media. Biotech. Lett., 18(5), 537-540.

Godden, B. and Penninckx, M.J., 1984. Identification and evolution of the cellulolytic microflora present during composting of cattle manure: on the role of actinomycetes sp. In Annales de l'Institut Pasteurl Microbiologie,135(1), 69-78.

Khan, A.W., Meek, E., Sowden, L.C., Colvin, J.R., 1984. Emendation of the Genus Acetivibrio and Description of Acetivibrio cellulosolvens sp. nov., a Nonmotile Cellulolytic Mesophile†. Int. J. Sys. Evo. Microbiol., 34(4), 419-422.

Kim, B.H. 1987. Carbohydrate catabolism in cellulolytic strains of Cellulomonas, Pseudomonas, and Nocardia. Kor. J. Microbiol., 25, 28-33.

Lin, L., Kan, X, Yan H., Wang D., 2012. Characterization of extracellular cellul ose-degrading enzymes from Bacillus thuringiensis strains. Elect. J. Biotechnol., 15(3), 1-6.

Ljungdahl, L.G., Bryant, F., Carreira, L., Saiki, T., Wiegel, J., 1981. Some aspects of thermophilic and extreme thermophilic anaerobic microorganisms. In Tren. Bio. Ferment. Fue. Chem., 397-419.

Lone M.A., Sahay S., Ravinder, Deepak, 
2014. Testing carboxymethyl cellulase activity secreted by Trichophyton terrestre in carboxymethyl cellulose solution. Amer. J. Microbiol., 5 (1), 18-26.

Lynd, L.R., Weimer, Z.W.H.V., Pretorius, I.S., 2002. Microbial cellulose utilization: fundamentals and biotechnology. Microbiol. Mole. Bio. Rev., 66(3), 506-577.

Lynd, L.R., Wyman C.E., Gerngross T.U., 1999. Biocommodity engineering. Biotechnol. Prog. 15, 777-793.

Maki, M.L., Broere, M., Leung, K.T., \& Qin, W., 2011. Characterization of some efficient cellulase producing bacteria isolated from paper mill sludges and organic fertilizers. Int. J. Biochem. Mol. Biol., 2(2), 146-154.

Manavalan, T., Manavalan, A., Heese, K., 2015. Characterization of lignocellulolytic enzymes from whiterot fungi. Curr. Microbiol., 70(4), 485-498.

Nanda, S., $\quad$ Sahu, S.S., 2010. Biodegradability of polyethylene by Brevibacillus, Pseudomonas, and Rhodococcus spp. New York Sci. J., 3(7), 95-98.

Nanda, S., Sahu, S., Abraham, J., 2010. Studies on the biodegradation of natural and synthetic polyethylene by Pseudomonas spp. J. App. Sci. Env. Manag., 14(2), 57-60.

Nwagu, K.E., Ominyi, M.C., Nwoba, G.E., 2012. Isolation, screening and measurement of amylase and cellulase activities of some microorganisms. Conti. J. Biologi. Sci., 5(1), 37-41.

Pandimadevi, M. and Begum, I.F., 2013. Screening, characterization and optimization of cellulase producing bacteria isolated from paper sludge. Int. J. Sci. Res., 2(9), 176-180.

Patagundi, B.I., Shivasharan, C.T., Kaliwal, B.B., 2014. Isolation and characterization of cellulase producing bacteria from soil. Int. J. Curr. Microbiol. App. Sci., 3(5). 59-69.

Raut, M.P., William, S.P., Bhattacharyya, J.K., Chakrabarti, T., Devotta, S., 2008. Microbial dynamics and enzyme activities during rapid composting of municipal solid waste-a compost maturity analysis perspective. Biore. Tech., 99(14), 6512-6519.

Sadasivam S. and Manickam A., 1991. Biochemical Methods. 2 edition, New age International Publication, 126128.

Shanmugam, S., Manavalan, R., Venkappayya, D., Sundaramoorthy, K., Mounnissamy, V.M., Hemalatha, S., Ayyappan, T., 2005. Natural polymers and their applications. Natl. Prod. Radiance., 4(6), 478-81.

Shanmugapriya, K., Saravana, P.S., Krishnapriya, Manoharan M., Mythili A., Joseph S., 2012. Isolation, screening and partial purification of cellulase from cellulase producing bacteria. Int. J. Adv. Biotechnol. Res., 3(1), 509-514.

Shi, Q.Q., Yu, H., Li, C., Bao, J., Xu, J., 2011. Catalytic performance of corn stover hydrolysis by a new isolate Penicillium sp. ECU0913 producing both cellulase and xylanase. App. Biochem. Biotechnol., 2011, 164, 819830.

Shu, G., Yang, H., Chen, H., Yang, Z., 2013. Research on extraction and characterization of cellulase from commercial enzyme preparation. $A d v$. J. F. Sci. Tech. 5(7), 839-842.

Singh, B., Sharma, N., 2008. Mechanistic implications of plastic degradation. Poly. Degra. Sta., 93(3), 561-584.

Soni, R., Kapri, A., Zaidi, M. G. H., Goel, R., 2009. Comparative biodegradation studies of non-poronized and 
poronized LDPE using indigenous microbial consortium. J. Poly. Env., 17(4), 233-239.

Svetlichny, V.A., Svetlichnaya, T.P., Chernykh, N., Zavarzin, G.A., 1990. Anaerocellum thermophilum gen. nov. sp. nov, an extreme thermophilic celluloselytic eubacterium isolated from hot springs in the Valley of Geysers. Microbiol. (Moscow), 59, 871-879.

Wachinger, G., Bronnenmeier, K.,
Staudenbauer, W.L., Schrempf, H., 1989. Identification of myceliumassociated cellulase from Streptomyces reticuli. App. Env. Microbiol., 55(10), 2653-2657.

Zhang, Y.H.P. and Lynd L.R. , 2004. Toward an aggregated understanding of enzymatic hydrolysis of cellulose: Noncomplexed cellulase systems. Biotechnol. Bioeng., 88, 797-824.

\section{How to cite this article:}

Vinay Mohan Pathak and Ajeet Singh, Navneet. 2016. Screening and Characterization of Cellulose Degrading Bacterial Isolates of Waste disposal Site. Int.J.Curr.Microbiol.App.Sci. 5(6): 898-907. doi: http://dx.doi.org/10.20546/ijcmas.2016.506.097 